\title{
ORGANIZATIONAL ENVIRONMENT OF OUTPATIENT DRUG TREATMENT SERVICES IN HUNGARY: A PILOT STUDY
}

\author{
Gábor Gazdag ${ }^{1,2}$, Gabor S. Ungvari, Rozália Takács ${ }^{4}$, József Rácz ${ }^{5,6}$ \\ ${ }^{1}$ Consultation-Liaison Psychiatric Service, Szent István and Szent László Hospitals, Budapest, Hungary \\ ${ }^{2}$ Department of Psychiatry and Psychotherapy, Faculty of Medicine, Semmelweis University, Budapest, Hungary \\ 3University of Notre Dame Australia, Marian Centre, Perth, Australia \\ ${ }^{4} 1$ st Department of Psychiatry, Nyiro Gyula Hospital, Budapest, Hungary \\ ${ }^{5}$ Institute for Psychology, Eotvos University, Budapest, Hungary \\ ${ }^{6}$ Blue Point Foundation, Budapest, Hungary
}

\section{SUMMARY}

Objectives: Organizations engaged in drug addiction treatment started their activities only recently in Hungary. This paper examines the organisational environment in drug outpatient treatment using the example of Blue Point Foundation (BPF), a non-governmental organization (NGO). The authors describe BPF's organizational structure and functioning related to its effectiveness.

Methods: BPF staff members anonymously completed a 59-item questionnaire about its organizational characteristics and functioning. The questionnaire covered demographic data, 50 items of the Quality Control questionnaire and a SWOT (Strengths, Weakness, Opportunities, Threats) analysis.

Results: Policy and strategy were considered BPF's best feature, while the management of funds received the lowest rating. The assessment of the staff and that of the organization as a whole was closer to the midpoint of the scale.

Discussion: High risk of staff burnout and unstable organizational environment are the most important threats on the NGOs working in addictology in Hungary.

Key words: addictology, organizational environment, burnout

Address for correspondence: Gábor Gazdag, Consultation-Liaison Psychiatric Service, Szent István and Szent László Hospitals, Gyáli út 5-7., Budapest, 1097 Hungary. E-mail:gazdag@lamb.hu

\section{INTRODUCTION}

While the development of the drug addiction treatment network began in the 1960s in the USA(1), in Hungary this process started about 20 years later, initiated by a few enthusiastic professionals. It took another decade until the first multi-disciplinary teams were set up. This was the time frame needed to organize the training of professionals and developing the social, political and financial conditions for drug addiction services. In Hungary (population 10 million), an important milestone of this development was the establishment of the National Drug Strategy (2), that marked out the main directions for the fight against drug addiction, provided a framework for the organizational structure of addictology care and also defined the course of its development. In the subsequent years a dynamic development of drug addiction services ensued. From 1996 to 2005, the number of organizations in this field increased by $50 \%(3,4)$. However, the dynamic increase in numbers was not followed by an improvement in the quality of drug addiction care. A recent questionnaire survey (5) targeted three regions of Hungary including the capital, altogether 54 non-governmental organizations (NGOs). The questionnaire inquired about interorganizational relationships (network analysis) and evaluation of up to 5 other organizations. The quality of services varied widely ranging from unacceptably low standard to evidencebased, high-quality care.

The Blue Point Foundation was one of the three organizations in the above study that received the highest prestige index.

The Blue Point Foundation (location: Budapest with a population of 2 million) is non-profit NGO that provides medical and psychosocial outpatient care for drug addicts. The Blue Point Foundation also runs a needle exchange service. This centre also provides HIV/AIDS and hepatitis $\mathrm{C}$ testing, counselling and community outreach. The services are free of charge; the source of funding is the National Health Fund and other state resources. In 2010, altogether 521 new clients approached the outpatient clinic of Blue Point Foundation amounting to 4,998 consultant-client meetings and 2,000 clients were registered in the low-threshold community centre.

In Hungary, the majority of addiction services is provided by outpatient clinics and social care centres that are part of the government-funded national health and social care system, respectively. Residential drug rehabilitation centres are also operated by NGOs, while acute inpatient services are located in state hospitals.

The main aim of recent organizational and management studies concerning drug addiction was to understand the organizational 
structure and management features related to effectiveness of service delivery $(6,7)$. Relevant topics included the team leaders' influence on organizational stability and staff fluctuation (8), the negative effect of the consultants' burn-out syndrome on client retention and efficiency of care $(9,10)$, the impact of consultants' burden on the development of burnout and the importance of the workplace environment (11).

The aim of the study was to determine the features of the Blue Point Foundation organizational structure and organizational environment that contribute to its performance in the light of the international literature. The study also attempted to explore some of the general features characteristic of NGOs that provide services for drug addicts in Hungary.

\section{METHODS}

\section{Subjects}

All 41 staff members of the Blue Point Foundation were invited to participate in the study by e-mail.

\section{The Questionnaire}

Participants anonymously completed a 59-item questionnaire about the organizational characteristics and functioning of the Blue Point Foundation. The questionnaire consisted of three parts: the first 5 questions inquired about demographic data, 50 items were added from the Quality Control (QC) questionnaire and 4 questions from the SWOT. Demographic data included respondents' gender, age, education, vocational training, and employment status.

To obtain information about the Blue Point Foundation functioning, the Hungarian version of the Quality Control questionnaire was used. This questionnaire developed by the Jellinek Institute was based on the European Foundation for Quality Management (EFQM) model (12). The questionnaire contains 50 items focusing on the following 9 areas: leadership, policy and strategy, people, partnerships and resources, processes, customer results, people results, society results, key performance results. The extent of agreement with the items is indicated on a 5-point Likert scale. At the end of the survey, participants were asked to evaluate the organization's internal and external situation by answering 4 questions of the SWOT analysis (13).

\section{RESULTS}

Altogether 22 Blue Point employees completed the questionnaire, a 54\% response rate. Respondents' mean age was $34 \pm 9.6$ years; 12 were men; $90 \%$ of respondents had a college or university degree $(n=19)$, one person each graduated from high and technical college. There were 3 medical practitioners (14\%), 4 psychologists $(19 \%), 8$ social workers (38\%), and 1 (4.8\%) mental health professional, educator, and consultant in addiction medicine. One person did not answer the previous two questions. Four of the respondents worked full time, 5 part-time and 9 were contract staff.

Responses given to the Quality Control questionnaire are shown in Table 1. Table 2 displays the image formed by the participants about the team itself and the features of the clients, relatives, and referring professionals. The characteristic responses from the SWOT analysis regarding the external (social, political) opportunities of the organization were: strengthening of international professional relationships, deployment of new services, extension of services for adolescents, improving the management of HCV infected clients, professional development and strengthening the opinion-leader role of the organization. Respondents also identified several external threats including burnout of staff, tensions between staff members, unfavourable political processes, difficulties with funding, leaving of key personnel, problems with the infrastructrue, high workload, and unfavourable changes in legal regulations, namely the tightening of the Penal Code.

\section{DISCUSSION}

To the best of our knowledge, this was the first study that explored the organizational characteristics of an NGO operating an outpatient drug addiction centre in Hungary. The organization surveyed is one of the most prestigious in this field in the country. The staff scored the organizations management at 3.9 on a 5-point rating scale. Professional policy and strategy were considered the best, while the lowest rating was given to the management of funds. The importance of financial sources is also in the SWOT analysis where it repeatedly appeared as a future threat to the organization. Financing through grants, which is common in this sector, generates a high level of uncertainty in Hungarian NGOs in this field.

Responses given by participants about the staff reflected significantly less favourable views about the Blue Point Foundation. The assessment of the organization was closer to the midpoint of the scale. In particular, tension at work and frequent sick leaves

Table 1. Ratings of the Quality Control questionnaire by the characteristics of Blue Point Foundation

\begin{tabular}{|l|l|}
\hline Group of questions & Mean \pm SD \\
\hline Leadership & $4.06 \pm 0.60$ \\
\hline Human resources management & $3.94 \pm 0.55$ \\
\hline Professional policy and strategy & $4.13 \pm 0.58$ \\
\hline Management of resources & $3.67 \pm 0.69$ \\
\hline Professional leadership & $3.83 \pm 0.97$ \\
\hline Process management & $3.84 \pm 0.72$ \\
\hline Total & $3.91 \pm 0.50$ \\
\hline
\end{tabular}

Table 2. Self-evaluation of the team based on the feedback from clients and relatives

\begin{tabular}{|l|l|}
\hline Group of questions & Mean \pm SD \\
\hline Self-evaluation of the team & $3.48 \pm 0.52$ \\
\hline Reflections from clients & $4.02 \pm 1.08$ \\
\hline Reflections from relatives & $3.76 \pm 1.49$ \\
\hline Reflections from referring professionals & $4.52 \pm 0.48$ \\
\hline General reflections & $3.62 \pm 1.30$ \\
\hline
\end{tabular}


appeared as serious problems indicating the risk of burnout. This was confirmed by the SWOT analysis where burnout was also among the social-political environment threatening the establishment. Although organizational interventions are helpful in reducing burnout, these measures can be difficult to implement in frontline community-based agencies for substance use disorders due to inadequate funding and unstable organizational environments (10).

Despite the negative image about the staff respondents' opinion based on feedback from clients and their relatives' social reflections fell between moderate and good. This indicates the low social status of addiction medicine even by employees of one of the most prestigious organizations in this field in Hungary. Respondents received the best feedback from referring professionals: Blue Point score was over 4.5 indicating satisfaction of the referring professionals with the organization's work.

Finally, items concerning the external environment from the SWOT analysis clearly reflect the current situation of the professional status of NGOs of this field. Although Hungary has one of the strictest legislation on drugs in the European Union (14), the present Government is planning to tighten the legislation further. Furthermore, the 2010 National Drug Strategy has also been revoked and the development of a new version is currently under way. All these changes have a critical impact on the working conditions and the future of the NGOs engaged in the care for substance abuse (15). Unfortunately, all these suggest that „The drug issue has been politicized in Hungary to such an extent that political decisions on drug policy are made without professional legitimization" (16).

\section{Limitations of the Study}

The results of this preliminary survey refer to one particular organization in drug addiction and cannot be generalised to all NGOs in this field, although the negative influences from the political and economical environment more or less equally affect all organizations. High workload level and consequently appearing burnout is also a general phenomenon of the field. The small number of participants and the relatively low participation rate also limits the generalizability of the results.

\section{REFERENCES}

1. Musto DF. Historical perspectives. In: Lowinson JH, Ruiz P, Millman RB, Langrod JG, editors. Substance abuse: a comprehensive textbook. 4th ed. Philadelphia PA: Lippincott Williams and Wilkins; 2005. p. 1-14.

2. National Drug Strategy. Budapest: Ministry of Social and Family Affaires; 2001. (In Hungarian.)

3. Rácz J. Treatment of drug abuse. In: Felvinczi K, Nyírády A, editors. Drug policy in numbers. Budapest: L'Harmattan; 2009. p. 189-232. (In Hungarian.)

4. Melles K, Márványkövi F, Rácz J. Low-threshold services for problem drug users in Hungary. Cent Eur J Public Health. 2007 Jun;15(2):84-6.

5. Arnold P, Paksi B. Civil organizations in the field of substance abuse. Addictologia Addict Hung. 2010;9(4):253-80. (In Hungarian.)

6. McConnell KJ, Hoffman KA, Quanbeck A, McCarty D. Management practices in substance abuse treatment programs. J Subst Abuse Treat. 2009 Jul;37(1):79-89.

7. McLellan AT, Carise D, Kleber HD. Can the national addiction treatment infrastructure support the public's demand for quality care? J Subst Abuse Treat. 2003 Sep;25(2):117-21.

8. Conger JA, Kanungo RN. Charismatic leadership in organizations. Thousand Oaks, CA: Sage; 1998.

9. Knudsen HK, Ducharme LJ, Roman PM. Counselor emotional exhaustion and turnover intention in therapeutic communities. J Subst Abuse Treat. 2006 Sep;31(2):173-80.

10. Vilardaga R, Luoma JB, Hayes SC, Pistorello J, Levin ME, Hildebrandt $\mathrm{MJ}$, et al. Burnout among the addiction counseling workforce: the differential roles of mindfulness and values-based processes and work-site factors. J Subst Abuse Treat. 2011 Jun;40(4):323-35.

11. Broome KM, Knight DK, Edwards JR, Flynn PM. Leadership, burnout, and job satisfaction in outpatient drug-free treatment programs. J Subst Abuse Treat. 2009 Sep;37(2):160-70.

12. Nabitz U, Klazinga N, Walburg J; European Foundation for Quality Management. The EFQM excellence model: European and Dutch experiences with the EFQM approach in health care. Int J Qual Health Care. 2000 Jun;12(3):191-201.

13. Hill T, Westbrook R. SWOT analysis: it's time for a product recall. Long Range Plan. 1997;30(1):46-52.

14. European Monitoring Centre for Drugs and Drug Addiction. European Legal Database on Drugs [Internet]. Lisbon: EMCDDA; 2011 [cited 2011 Jun 14]. Available from: http://www.emcdda.europa.eu/eldd.

15. Curth NK, Hansson LN, Storm F, Lazarus JV. Select barriers to harmreduction services for IDUs in eastern Europe. Cent Eur J Public Health. 2009 Dec;17(4):191-7.

16. Gerevich J, Szabó L, Polgár P, Bácskai E. Innovations: Alcohol \& drug abuse: Methadone maintenance in Europe and Hungary: degrees of sociocultural resistance. Psychiatr Serv. 2006 Jun;57(6):776-8.

Received August 29, 2011 Accepted in revised form August 8, 2012 